[Agr. Biol. Chem., Vol. 30, No. 2, p. 99 106, 1966]

\title{
Enzymatic Determination of 5-Phosphoribosylpyrophosphate
}

\author{
By Yuji Nagano, Keiichi Inuzuka, Hirotoshi Samejima \\ and Shukuo Kinoshita \\ Tokyo Research Laboratory, Kyowa Hakko Kogyo Co., Ltd., Tokyo \\ Received August 13, 1965
}

\begin{abstract}
An enzymatic method for determination of 5-phosphoribosylpyrophosphate (PRPP) was investigated. The method was based on a coupled reaction of orotidine- 5 -monophosphate pyrophosphorylase and orotidine- 5 -monophosphate decarboxylase obtained as cell-free extract from a mutant strain of Micrococcus glutamicus (Syn. Corynebacterium glutamicum). The enzymes catalyzed quantitative conversion of orotic acid to uridine-5'-monophosphate. In the method, the consumption of orotic acid was determined by measuring optical density at $295 \mathrm{~m} \mu$ and then PRPP was calculated from the amount of orotic acid consumed. The conditions of the enzyme reaction were examined in detail, and a modified method for determination of PRPP involving termination of the enzyme reaction by EDTA was established. According to the present method, $10^{-1} \mu \mathrm{mol}$. of PRPP is determined with accuracy of $100 \pm 3 \%$ within 30 minutes. As an application of the method, chemical stability of PRPP was examined and the results were described.
\end{abstract}

\section{INTRODUCTION}

5-Phosphoribosylpyrophosphate (PRPP) is known as an important intermediate in the biosynthetic pathways of nucleotides and some amino acids such as histidine and tryptophan. Therefore, it is quite useful for biosynthetic studies of such compounds to establish a simple and reliable method for determining PRPP.

Pure PRPP has often been determined by quantitative analysis of ribose or phosphate moiety of the compound. However, in most of natural materials, various ribose polyphosphates are present together with PRPP. This makes the determination of PRPP much difficult, and complicate separation procedures are often needed for determining PRPP in natural materials. Remy et al. " reported on separation and identification of PRPP by ion exchange resin chromatography of ribose polyphosphates with Dowex 1 (formate form). Lieberman et al. ${ }^{2}$ also reported on the same

1) C. N. Remy, W. T. Remy and J. M. Buchanan, J. Biol. Chem., 217, 885 (1955).

2) L. Lieberman, A.T. Kornberg and E.S. Simms, ibid. 215, 403 (1955). problem, and further investigated the determination of PRPP by an enzymatic method. The method was based on quantitative conversion of orotic acid and PRPP to uridine-5'monophosphate (5'-UMP) which was catalyzed by an enzyme preparation extracted from dried brewer's yeast.

In the preceding paper, ${ }^{31}$ the authors studied on the enzymatic conversion of orotic acid to 5 '-UMP with cell-free extract of Micrococcus glutamicus (Syn. Corynebacterium glutamicum) 534 Co-147 strain. And, it was recognized that the reaction proceeded according to the following scheme:

$$
\begin{aligned}
& \text { 5'-OMP pyrophosphorylase; } \\
& \text { Orotate+PRPP } \rightleftarrows 5^{\prime} \text {-OMP }+\mathrm{PPi} \\
& \text { 5'-OMP decarboxylase; } \\
& \text { 5'-OMP } \longrightarrow 5^{\prime} \text {-UMP }+\mathrm{CO}_{2}
\end{aligned}
$$

$$
\text { Orotate }+\mathrm{PRPP} \rightarrow 5^{\prime}-\mathrm{UMP}+\mathrm{PPi}+\mathrm{CO}_{2}
$$

The conversion reaction from orotate to $5^{\prime}$ UMP was followed spectrophotometrically by

3) Y. Nagano, H. Samejima and S. Kinoshita, This Journal, 3o, 83 (1966). 
measuring the decrease of optical density at $295 \mathrm{~m} \mu$ which was caused by the consumption of orotate.

In the present paper, a modified method for the determination of PRPP, which is based on a coupled reaction of $5^{\prime}$-OMP pyrophosphorylase and 5'-OMP decarboxylase, is described. The principles of the method are as follows:

(i) In the reaction mixture, orotate is converted to $5^{\prime}$-UMP according to the equation (3). (ii) The consumption of orotate at the completion of the enzymatic reaction is determined by measuring the decrease of optical density at $295 \mathrm{~m} \mu$. And, (iii) PRPP in the reaction mixture is calculated stoichiometrically from the amount of orotate consumed. Using an enzyme preparation from Micrococcus glutamicus 534 Co-147 strain, conditions of PRPP determination were investigated in detail. Especially, as EDTA was found to be a strong reaction regulator, addition of EDTA was conveniently applied for the termination of the enzyme reaction. This made the present method more practical when many samples should be assayed.

According to the method, $10^{-1} \mu \mathrm{mol}$ of PRPP could be determined with accuracy of $100 \pm 3 \%$ within 30 minutes. The present method can be said to be a rapid and specific microdetermination for PRPP in respect of that the enzyme used is quite specific only for PRPP among various ribose polyphosphates and the reactant can be spectrophotometrically measured. As an example of application of the present method, chemical stabilities of PRPP against temperature and $\mathrm{pH}$ changes were examined.

\section{MATERIALS AND METHODS}

\section{Preparation of Enzyme Solution.}

Cultivation of M. glutamicus $534 \mathrm{Co}-147$ and preparation of cell-free extract from the bacterial cells were carried out as described in the preceding paper. $\left.{ }^{3}\right)$ The cell-free extract was divided into small portions and stored frozen in a refrigerator at $-20^{\circ} \mathrm{C}$. In this condition, the cell-free extract was kept without any loss of enzyme activity for at least one month.
This stock solution was melted at room temperature and diluted with $0.1 \mathrm{M}$ Tris buffer $(\mathrm{pH} \mathrm{9.0)}$ to an appropriate concentration, usually 2.0 units of enzyme activity per $\mathrm{ml}$, before use.

\section{Chemicals and Instruments.}

Orotic acid and PRPP were obtained from Kyowa Hakko Kogyo Co., Ltd., Tokyo and Sigma Chemicals Co., St. Louis, Missouri, respectively.

As spectrophotometric devices, Hitachi Recording Spectrophotometer EPS-2 (Hitachi Ltd., Tokyo) was used for the determination of enzyme activity and Hitachi Photoelectric Spectrophotometer EPU-2A for the determination of PRPP.

\section{Determination for Enzyme Activity.}

As described in the preceding paper, ${ }^{3)}$ the progress of the enzyme reaction is followed by measuring the decrease of optical density at $295 \mathrm{~m} \mu$ which is based on the enzymatic conversion of orotic acid to 5 '-UMP. Therefore, the enzyme activity is determined from the consumption rate of orotate, i.e., the decrease of optical density at $295 \mathrm{~m} \mu$ per unit time.

Activity was calculated from extraporation of initial rate of the reaction. And, one unit of enzyme activity was defined as an amount of enzyme which was able to consume $1 \mu \mathrm{mol}$. of orotic acid for one hour.

(1) Reagents:

$100 \mathrm{mM}$ Tris buffer (pH 9.0)

$10 \mathrm{mM} \mathrm{MgCl}_{2}$

$0.5 \mathrm{~mm}$ Sodium orotate

$0.4 \mathrm{mM}$ PRPP

Enzyme solution (for sample)

(2) Procedure:

The enzyme reaction is carried out in a quartz photocuvette $\left(5 \mathrm{ml}, 1 \mathrm{~cm}\right.$ light path) at $30^{\circ} \mathrm{C}$. In this cuvette $0.5 \mathrm{ml}$ each of $100 \mathrm{mM}$ Tris buffer ( $\mathrm{pH} \mathrm{9.0),}$ $10 \mathrm{mM} \mathrm{MgCl} 2,0.5 \mathrm{~mm}$ sodium orotate, and $0.4 \mathrm{mM}$ PRPP are added in order. Finally $0.5 \mathrm{ml}$ of enzyme solution is combined to the reaction mixture and immediately the optical density at $295 \mathrm{~m} \mu$ is measured at zero time. After incubation for 10 minutes at $30^{\circ} \mathrm{C}$, the optical density at $295 \mathrm{~m} \mu$ is again measured. The decrease of optical density for 10 minutes is read from the difference of optical densities between at zero time and 10 minutes, and this value is designated as $-\Delta E$. In order to cancel the ultraviolet absorption of the enzyme solution, $0.5 \mathrm{ml}$ of $100 \mathrm{mM}$ Tris buffer ( $\mathrm{pH} 9.0), 0.5 \mathrm{ml}$ of enzyme solution and $1.5 \mathrm{ml}$ of water are added in the reference cuvette.

(3) Calculation:

From $-\Delta E$ value measured as described above, 
enzyme activity of the enzyme solution was calculated according to the following formula:

Enzyme Activity (unit $/ \mathrm{ml}$ )

$$
\begin{aligned}
& =0.1 \times 1 / 0.396 \times 5 \times(-\Delta E) \times 6 \\
& =7.6 \times(-\Delta E)
\end{aligned}
$$

where the molar extinction coefficient of orodic acid is 3950. A linear relationship between enzyme activity and $-\Delta E$ (decrease of optical density at 295 $\mathrm{m} \mu$ for 10 minutes) was observed in enzyme activity ranging from 0 to 1.0 unit $/ \mathrm{ml}$.

\section{Determination for PRPP.}

PRPP is calculated stoichiometrically from the amount of orotic acid consumed in the enzyme reaction which proceeds according to the equation (3). Optical density of the enzyme reaction mixture is measured both at zero time and after 30 minutes incubation. The amount of orotic acid consumed is determined from the decrease of optical density for 30 minutes. EDTA is successfully used as stopping agent for the reaction.

(1) Reagents:

$100 \mathrm{~mm}$ Tris buffer $(\mathrm{pH} 9.0)$

$10 \mathrm{mM} \mathrm{MgCl}_{2}$

$0.5 \mathrm{mM}$ sodium orotate

Enzyme solution (more than 1 unit/ml)

$50 \mathrm{mM}$ EDTA $2 \mathrm{Na}$ (adjust to $\mathrm{pH} 9.0$ with $\mathrm{NaOH}$ )

PRPP solution (for sample)

(2) Procedure:

The reaction mixture $(8 \mathrm{ml})$ containing $2 \mathrm{ml}$ each of $100 \mathrm{~mm}$ Tris buffer, $10 \mathrm{mMMgCl}_{2}, 0.5 \mathrm{mM} \mathrm{Na}$ orotate and enzyme solution was prepared. Four $\mathrm{ml}$ of the reaction mixture were taken into a test tube and $1 \mathrm{ml}$ of sample was added. After incubation for 30 minutes at $30^{\circ} \mathrm{C}$, the reaction was stopped by addition of $1 \mathrm{ml}$ of $50 \mathrm{mM}$ EDTA. This solution was designated as $\mathrm{A}$. To $4 \mathrm{ml}$ of the remainder, $1 \mathrm{ml}$ of $50 \mathrm{mM}$ EDTA and $1 \mathrm{ml}$ of sample solution were added. This solution was designated as B. $4 \mathrm{ml}$ each of Tris buffer were added to both $A$ and $B$ solutions and optical densities of both diluted solutions were measured at $295 \mathrm{~m} \mu$, respectively. The difference of the optical density between $A$ and $B$ solutions were designated as $-\Delta E^{\prime}$.

(3) Calculation:

From $-\Delta E^{\prime}$ described above, the concentration of PRPP in sample solution is calculated according to the following formula:

$\operatorname{PRPP}(\mu \mathrm{mol} / \mathrm{ml})=0.1 \times 1 / 0.395 \times 5 \times\left(-\Delta E^{\prime}\right) \times 2$

$$
=2.54 \times\left(-\Delta E^{\prime}\right)
$$

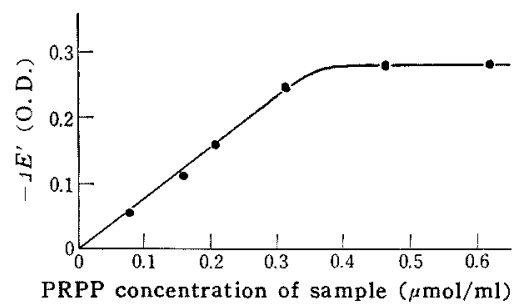

FIG. 1. Relation between Concentration and $-\Delta E^{\prime}$.

$-\Delta E^{\prime}$ represents the decrease of optical density at $295 \mathrm{~m} /$ when the reaction mixture was incubated for 30 minutes.

$$
\begin{aligned}
\text { PRPP }(\mathrm{mg} / \mathrm{ml}) & =2.54 \times 0.389 \times\left(-\Delta E^{\prime}\right) \\
& =0.988 \times\left(-\Delta E^{\prime}\right)
\end{aligned}
$$

As shown in Fig. 1 under the conditions of the present method, there was found a linear relationship between PRPP concentration and $-\Delta E^{\prime}$ in a range from 0 to $0.3 \mu \mathrm{mol} / \mathrm{ml}$ of PRPP.

\section{RESULTS}

On the Conditions for the Determination of Enzyme Activity.

In order to establish a method for PRPP determination, it is important to use an enzyme solution with a known enzyme activity. Therefore, the authors studied, at first, on the conditions for the determination of enzyme activity.

1) Time course of the enzyme reaction.

A unit of enzymatic activity was defined as an amount of enzyme causing the removal of $1 \mu \mathrm{mol}$ of orotic acid in one hour, and practically it was calculated from extraporation of the initial reaction rate. Therefore, in order to establish condition for measuring the initial reaction rate, the time courses of the reaction were examined.

In the experiments, $1 / 6$ diluent of stocked cell-free extract with $0.1 \mathrm{~m}$ Tris buffer $(\mathrm{pH}$ 9.0) was used as an enzyme solution. (This enzyme solution was later found to have 0.98 unit $/ \mathrm{ml}$ of enzyme activity.) The reaction mixture contained $0.5 \mathrm{ml}$ each of $100 \mathrm{~mm}$ Tris buffer (pH 9.0), $10 \mathrm{~mm} \mathrm{MgCl}_{2}, 0.5 \mathrm{~mm}$ $\mathrm{Na}$-orotate, the enzyme solution $(0.98 \mathrm{unit} / \mathrm{ml})$ and PRPP solution of varied concentration. 


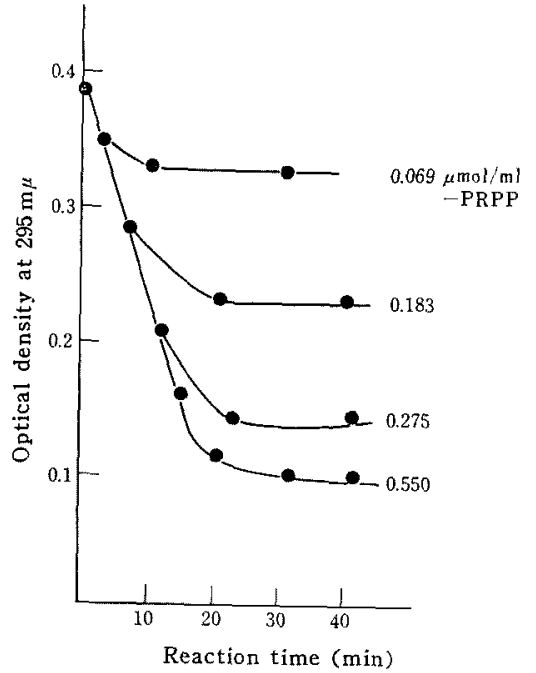

FIG. 2. Time Caurse of Enzyme Reaction with PRPP Solutions of Varied Concentrations.

The reaction mixture contained $\mathrm{Tr}$ is buffer, $\mathrm{MgCl}_{2}$, Naorotate, enzyme $(0.98 \mathrm{unit} / \mathrm{ml})$ and PRPP of varied concen. tration. Incubation was carried out at $30^{\circ} \mathrm{C}$.

The incubation was carried out at $30^{\circ} \mathrm{C}$. The progress of the enzyme reaction was followed by measuring the decrease of the optical density at $295 \mathrm{~m} \mu$, as shown in Fig. 2. The initial linear part of the reaction curve should be used for the enzyme assay. As shown in Fig. 2, in order to get accurate result in measuring reaction rate, it was desirable to measure optical density change for 10 minutes Therefore, in later experiments, reaction rate was determined from the decrese of optical density at $295 \mathrm{~m} \mu$ for 10 minutes.

2) Effect of PRPP concentration on reaction rate.

In order to decide the concentration of PRPP required for measuring the reaction rate, effect of the concentration of PRPP on the reaction rate was further examined.

As shown in Fig. 3, the reaction rate was dependent on the concentration of PRPP if PRPP solution with less than $0.3 \mu \mathrm{mol} / \mathrm{ml}$ was used. If PRPP solution whose concentration was more than $0.3 \mu \mathrm{mol} / \mathrm{ml}$ was used, the initial rate of reaction became independent

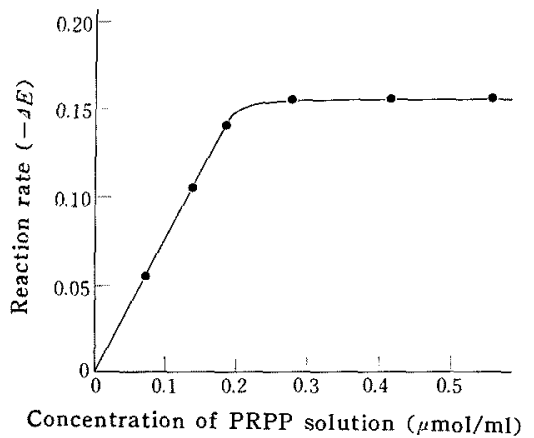

FIG. 3. Effect of Concentration of PRPP on Reaction Rate.

The reaction rates $(-A E)$ were determined by measuring the decrease of optical density at $295 \mathrm{~m} \psi$ for 10 minutes.

from PRPP concentration. Therefore, in later experiments, $0.4 \mathrm{~mm}$ PRPP solution was used for the determination of the enzyme activity.

3) Relation between reaction rate and enzyme activity.

Under the conditions decided in the preceding experiments, relation between reaction rate and enzyme activity was examined. As enzyme solutions, various diluents of an enzyme solution containing $2.16 \mathrm{unit} / \mathrm{ml}$ of activity were used. In the experiment, 0.4 mM PRPP solution was used, and reaction rates were measured. The result is shown in Fig. 4. From Fig. 4, linear relationship between the enzyme concentration and the

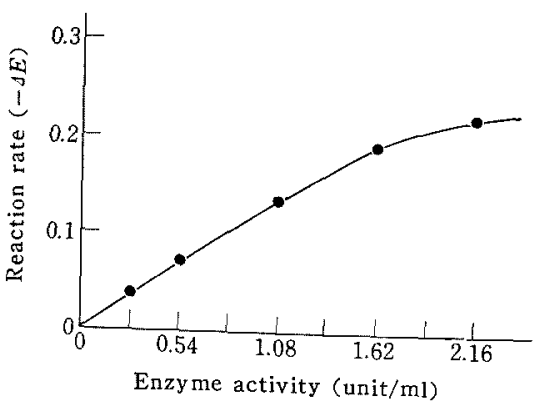

FIG. 4. Relation betwcen Enzyme Activity and Reaction Rate.

The reaction mixture was identical with that in Fig. 1, except that PRPP solution of $0.4 \mu \mathrm{mol} / \mathrm{ml}$ and enzyme solu. tions of various activities were used. 
reaction rate was observed in the range from 0 to $1.1 \mathrm{unit} / \mathrm{ml}$ of enzyme activity. Therefore, in later experiments, enzyme solution was diluted within such range when the enzyme activity was determined.

On the Conditions for the Determination of PRPP.

1) Relation between enzyme activity and reaction time.

In order to decide the enzyme activity and reaction time required for the determination of PRPP, the time courses of the reaction with the enzyme solutions of various concentrations were studied. The reaction mixture contained $0.5 \mathrm{ml}$ each of $100 \mathrm{~mm}$ Tris buffer (pH 9.0), $10 \mathrm{~mm} \mathrm{MgCl}_{2}, 0.5 \mathrm{~mm}$ Na-orotate, 0.25 mM PRPP and enzyme solution of varied activity. After addition of enzyme solution, the optical density was immediately measured and then measurements of optical density were done every 10 minutes. The time courses of the reaction are shown in Fig. 5. The reactions were not completed within one hour if the enzyme solution with so low

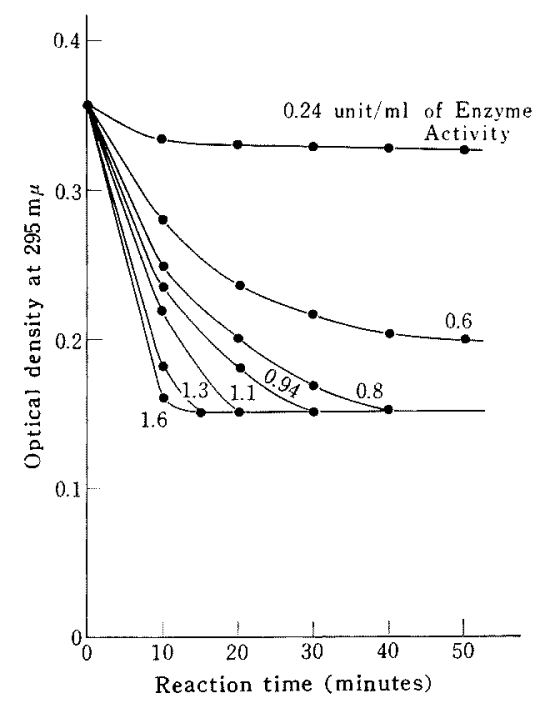

FIG. 5. Time Courses of Reaction with Enzyme Solution of Varied Activities.

The reaction mixture contained Tris buffer, $\mathrm{MgCl}_{2}$, Na orotate, PRPP of $0.25 \mathrm{~mm}$ and enzyme of varied activities.

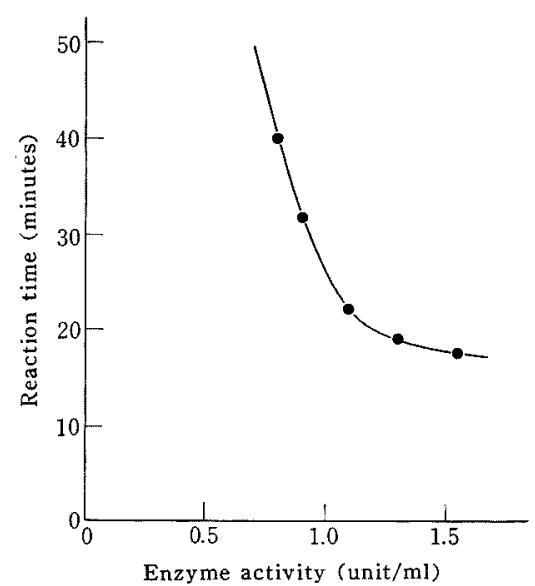

FIG. 6. Relation between Enzyme Activity and Reaction Time.

Reaction time represents the time required for the quantitative conversion of orotic acid to $5^{\prime}$-UMP.

activity as less than $0.6 \mathrm{unit} / \mathrm{ml}$ was used. The reaction time required for the completion of the enzyme reaction corresponding to each activity of enzyme solution was read from Fig. 5, and plotted in Fig. 6. From practical point of view, the reaction time should be adopted as short as possible. Therefore, the authors tentatively decided to set the length of the reaction time as 30 minutes. As shown in Fig. 6, it was necessary to employ an enzyme solution whose activity was more than 1.0 unit $/ \mathrm{ml}$, in order to complete the enzyme reaction within 30 minutes.

2) Termination of enzyme reaction by EDTA.

PRPP is determined by measuring the decrease of optical density at $295 \mathrm{~m} \mu$ during the enzyme reaction. Therefore, the enzyme reaction should be stopped at zero time and at 30 minutes after the initiation of the reaction. EDTA was found to be an excellent stopping agent for the reaction.

Therefore, in order to decide the concentration of EDTA as a stopping agent, the effect of EDTA concentration on the enzyme activity was examined. As shown in Fig. 7, it was found that addition of EDTA solution 


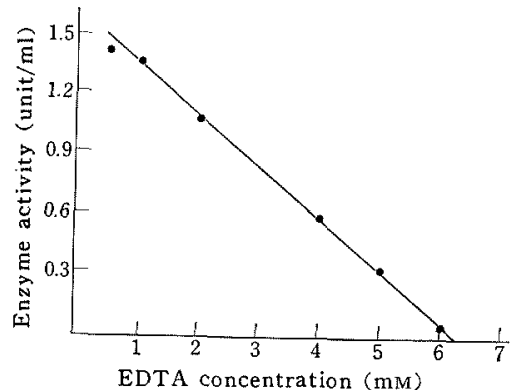

Frg. 7. Inhibition of Enzyme Activity by EDTA.

The reaction mixture was identical with that in Fig. 4 , except that enzyme solution of $1.7 \mathrm{unit} / \mathrm{ml}$ was used. $0.5 \mathrm{ml}$ of EDTA of varied concentrations was added to the reaction mixture and the enzyme activities were assayed.

of more than $6 \mathrm{~mm}$ could completely inactivate the enzyme activity even when an enzyme solution with $1.7 \mathrm{unit} / \mathrm{ml}$ of activity was employed. This can be reasonably explained as the strong chelation by EDTA of $\mathrm{Mg}$ ion which is an essential participant for the reaction. Therefore, EDTA solution of fairly high concentration ( $50 \mathrm{~mm}$ ) was used as a stopping agent in the later PRPP assay.

3) Measurable range of PRPP Concentration.

From the results of preceding experiments, the conditions for the determination of PRPP were decided as described in the previous chapter, i.e., "Materials and Methods." Under the conditions, measurable range of PRPP concentration for the determination was examined. From Fig. 1, it is observed that there is a linear relation between PRPP concentration and $-\Delta E^{\prime}$ in the range from 0 to $0.3 \mu \mathrm{mol} / \mathrm{ml}$ of PRPP.

\section{PRPP Recovery Test.}

In order to examine the accuracy of the present PRPP assay, PRPP recovery tests were carried out. Various known amounts of PRPP were added in $10 \mathrm{ml}$ of the preheated fermentation broth of $M$. glutamicus, and the amounts of PRPP were determined according to the present method. From the amounts of PRPP found, the recoveries of PRPP added were calculated. The results are listed in
TABLE I. RECOVERY OF PRPP ADDED IN THE SUPERNATANT OF FERMENTATION BROTH

$\begin{array}{cccc}\begin{array}{c}\text { Experimental } \\ \text { No. }\end{array} & \begin{array}{c}\text { PRPP added } \\ (\mu \text { mol. })\end{array} & \begin{array}{c}\text { PRPP found } \\ (\mu \text { mol. })\end{array} & \begin{array}{c}\text { Recovery } \\ (\%)\end{array} \\ 0.00 & 0.00 & 0 \\ 0.00 & 0.00 & 0 \\ 0.50 & 0.51 & 102 \\ 0.50 & 0.50 & 100 \\ 1.50 & 0.47 & 98 \\ 1.50 & 1.53 & 102 \\ 2.50 & 2.45 & 98 \\ 2.50 & 2.42 & 97 \\ 0.00 & 0.00 & 0 \\ 0.50 & 0.51 & 102 \\ 1.50 & 1.50 & 100 \\ 2.50 & 2.42 & 97\end{array}$

Table I. As shown in Table I, PRPP in natural material was determined with the accuracy of $100 \pm 3 \%$.

\section{Stability of PRPP.}

As a practical application of the present enzymatic assay method, chemical stabilities of PRPP in aqueous solution were determined. Stability of PRPP against $\mathrm{pH}$ change was examined by treating PRPP solution (2.0$\mu \mathrm{mol} / \mathrm{ml}$ ) in various buffers of different $\mathrm{pH}$ at $60^{\circ} \mathrm{C}$ for 20 minutes. As shown in Fig. 8 , PRPP was fairly stable between $\mathrm{pH} 5$ and 9 . While, it becomes labile at $\mathrm{pH}$ less than 5 or more than 9. Especially, at $\mathrm{pH}$ less than 3 or more than 12, PRPP was completely destroyed under the experimental conditions.

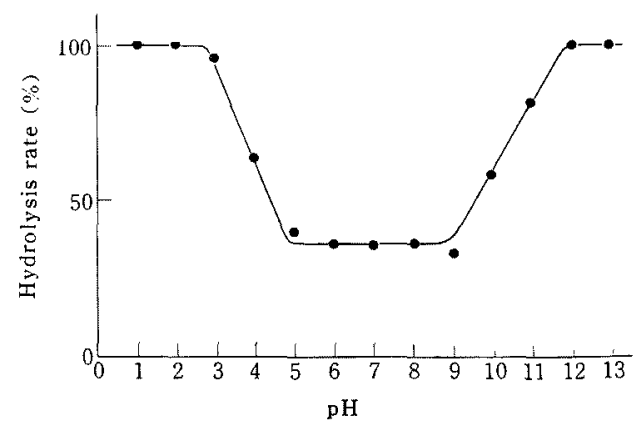

FIG. 8. pH Stability of PRPP.

$P R P P$ in buffers of various $\mathrm{pH}$ values were treated at $60^{\circ} \mathrm{C}$ for 20 minutes. 


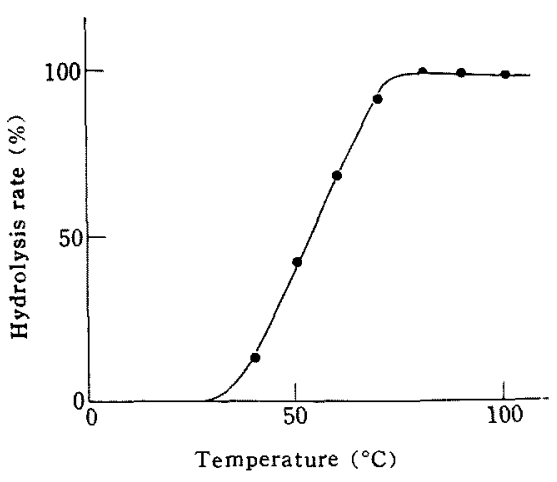

F1G. 9. Heat Stability of PRPP.

Aqueous PRPP solution $(2 \mu \mathrm{mol} / \mathrm{ml})$ at $\mathrm{pH} 4.0$ was treated at various temperatures for 20 minutes.

Stability of PRPP against temperature was also examined by treating aqueous PRPP solution of $\mathrm{pH} 4.0$ at various temperatures for 20 minutes. As shown in Fig. 9, PRPP is stable at below $30^{\circ} \mathrm{C}$ but it becomes unstable at more than $30^{\circ} \mathrm{C}$. Especially, PRPP was completely destroyed at more than $80^{\circ} \mathrm{C}$ under the experimental conditions.

Pyrophosphate moiety at carbon 1 of PRPP was easily attacked by diluted acid and alkali at room temperature and this resulted in formation of ribose-5-phosphate (R-5-P) and 5-phosphoribosylphosphate (PRP), respectively. ${ }^{4}$ The phosphate ester bound at carbon 5 of ribose moiety was known to be fairly stable and hydrolyzed by treating with $1 \mathrm{~N}$ $\mathrm{HCl}$ at $100^{\circ} \mathrm{C}$ for 2 hours.

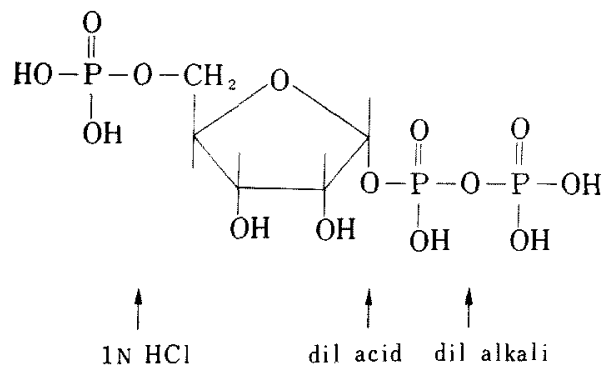

4) H. G. Korana, J. F. Fernandes and A. T. Kornberg, 7 . Biol. Chem., 230, 941 (1958).
Therefore, the degradation of PRPP in the preceding experiments might be caused by hydrolysis of pyrophosphate moiety with diluted acid and alkali according to the manner shown above.

\section{DISCUSSION}

In the enzymatic method for PRPP determination reported by Lieberman et al., ${ }^{2}$ the enzyme reaction was carried out at $\mathrm{pH} 8.0$ in a quartz photocuvette fixed in a spectrophotometer. Therefore, in the method, samples were determined one after another. However, it is often needed that many PRPP samples must be determined in a short time. For the speed-up of the PRPP determination, the authors have taken the following measures:

As the first measure, the reaction time required for completion of the enzyme reaction was shortened by employing an enzyme solution with relatively high activity obtained from a strain of $M$. glutamicus and choosing optimum $\mathrm{pH}(\mathrm{pH} \mathrm{9.0)}$ for 5'-OMP pyrophosphorylase reaction, instead of $\mathrm{pH}$ 8.0. The effect of $\mathrm{pH}$ on the 5'-OMP pyrophosphorylase reaction will be published elsewhere. ${ }^{5}$

Then, as the second measure, the enzyme reaction and optical density measurement were done in different vessels. In order to make this way practical, some effective measures were needed to stop the enzyme reaction freely at any time.

Hithertofore, enzyme reactions have often been stopped by heating. In the present instance, the enzyme activity was effectively lost by heating the reaction mixture at $70^{\circ} \mathrm{C}$. for 10 minutes. However, this treatment resulted in severe turbidity in the reaction mixture, and made optical density measurement impossible. As another measure for stopping the reaction, addition of acid was tried. Though the enzyme reaction was completely stopped at $\mathrm{pH}$ below 7.0, such $\mathrm{pH}$ change was not applicable for the deter-

5) Y. Nagano, K. Inuzuka, H. Samejima and S. Kinoshita will be contributed in this Journal. 
mination because of remarkable change of UV spectrum and molar extinction coefficient of orotic acid around pH 7.0 (See Table II).

TABLE II. UV ABSORPTION OF SODIUM OROTATE AT DIFFERENT $\mathrm{pH}$

$\begin{array}{ccc}\mathrm{pH} & \lambda_{\max }(\mathrm{m} \mu) & \mathrm{Ex}\left(10^{-3}\right) \\ 7.0 & 278.5 & 7.68 \\ 8.0 & 281.5 & 6.58\end{array}$

During the investigation on the properties of $5^{\prime}$-OMP pyrophosphorylase obtained from $M$. glutamicus strain, ${ }^{5}$ it was found that the enzyme activity was inhibited by addition of EDTA. As shown in Fig. 7, addition of enough amount of EDTA had completely stopped the enzyme reaction at once. More favorably, addition of EDTA did not accompany any turbidity formation and $\mathrm{pH}$ change, and was successfully used as a stopping agent for the enzyme reaction.

From this finding, parallel incubation of many reaction mixtures has become possible, and many PRPP samples have been determined within much shorter time.

The accuracy of the present method was also found to be $100 \pm 3 \%$. Therefore, the present method can be said to be a rapid and specific microdetermination for PRPP in natural materials. 